\title{
Contribution to the knowledge of genus Phradonoma (Jacquelin du Val, 1859) from the Afrotropical Region (Coleoptera: Dermestidae: Megatominae)
}

\author{
JIŘÍ HÁvA \\ ${ }^{1}$ Daugavpils University, Institute of Life Sciences and Technology, \\ Coleopterological Research Center, Vienības Str. 13, Daugavpils, LV - 5401, Latvia \\ ${ }^{2}$ Private Entomological Laboratory and Collection, Rýznerova 37, CZ - 25262 Únětice u Prahy, \\ Praha-západ, Czech Republic e-mail: jh.dermestidae@volny.cz
}

\begin{abstract}
Háva, J.: Contribution to the knowledge of genus Phradonoma (Jacquelin du Val, 1859) from the Afrotropical Region (Coleoptera: Dermestidae: Megatominae).

Abstract: The species Phradonoma geiseri sp. nov. from Namibia and Ph. tsavoensis sp. nov. from Kenya are described, illustrated and compared with all known Afrotropical species belonging to the "Phradnonoma nobile species group". The new species are characteristic by their structure of antennae and male genitalia and elytral colour setation. The species Ph. nobile (Reitter, 1881) is newly recorded from Senegal, Ph. angelusi Háva \& Herrmann, 2009 from Kenya and Ph. borowieci Háva \& Kadej, 2006 from Zimbabwe. Keys to Afrotropical Phradonoma species are provided.
\end{abstract}

Keywords: taxonomy, new species, new records, description, Coleoptera, Dermestidae, Phradonoma, Afrotropical Region.

\section{Introduction}

The genus Phradonoma currently contains 44 species distributed in Palaearctic and Afrotropical Regions, only one species was introduced into USA and Australia (HÁvA 2015, Háva \& HoRÁK 2017).

During the determination of some Dermestidae material deposited in British Museum Natural History, London, England, and author's collection, the present author found two new Phradonoma Jacquelin du Val, 1859 species from Namibia and Kenya described below. Three species are newly recorded.

\section{Material and methods}

The size of the beetles or of their body parts can be useful in species recognition and thus, the following measurements were made:

TL: total length - linear distance from anterior margin of pronotum to apex of elytra.

EW: elytral width - maximum linear transverse distance. 
The type specimens are deposited in the following collections:

BMNH: British Museum Natural History Museum, London, England;

JHAC : Jiří Háva, Private Entomological Laboratory \& Collection, Únětice u Prahy, Prague-West, Czech Republic.

Specimens of the presently described species are provided with red, printed labels with text as follows: 2019".

„HOLOTYPE (or PARATYPE, respectively) species name sp. nov. Jiří Háva det.

The nomenclature and zoogeography follow Háva (2015).

\section{Results}

Phradonoma geiseri sp. nov. (Figs. 1,3,4)

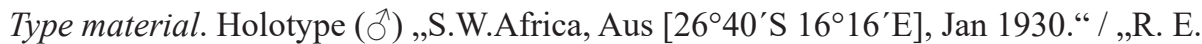
Turner. Brit. Mus. 1930-117“, (BMNH). Paratypes (4 spec.): the same data as holotype (3 BMNH, 1 JHAC).

Description of male holotype. Body brown, longish oval. Body measurements (mm): TL 1.9 EW 1.2. Head coarsely punctuated, with long more or less decumbent light brown setae, maxillary palpi dark brown, eye large with microsetae, antennae with 11 antennomeres with 5 antennomered club. First antennomere brown, club very darkish brown and all other segments light brown (Fig. 1). Forehead with ocellus. Pronotum entirely dark brown, shiny, sparsely and not very coarsely punctated, with strong dark and slightly erect setae, white setae forming small patches antero-laterally; other parts covered by light brown setae. Lateral margins not visible from above. Scutellum small, dark brown, triangular, without setation or punctures. Elytra dark brown anteriorly, light brown posteriorly without reddish or orange patches, sparsely and coarsely punctated and covered by sparsely, slightly erect brown and white setation. Each elytron with three transverse narrow fasciae of white setae. Underside of specimen coarsely and (especially visible ventrite) more densely punctate than elytra and pronotum, covered with straight and procumbent brown setae. Tibiae and tarsi brown, femura anteriorly darkened and sparsely covered with fine brown hairs. Male genitalia as in Fig. 4, tip of median lobe as in Fig. 3.

Female. Externally very similar to male, but antenna a little bit shorter and club also slightly smaller than that male.

Variabilty. Body measurements (mm): TL 1.91-2.17.

Diagnosis. The new species belongs to the "Phradnonoma nobile species group" defined by Háva et al. (2013). The new species differs from other known Afrotropical species belonging to the species group by the characters mentioned in the keys below.

Etymology. Patronymic, dedicated to the curator of Coleoptera Michael Geiser (BMNH). 

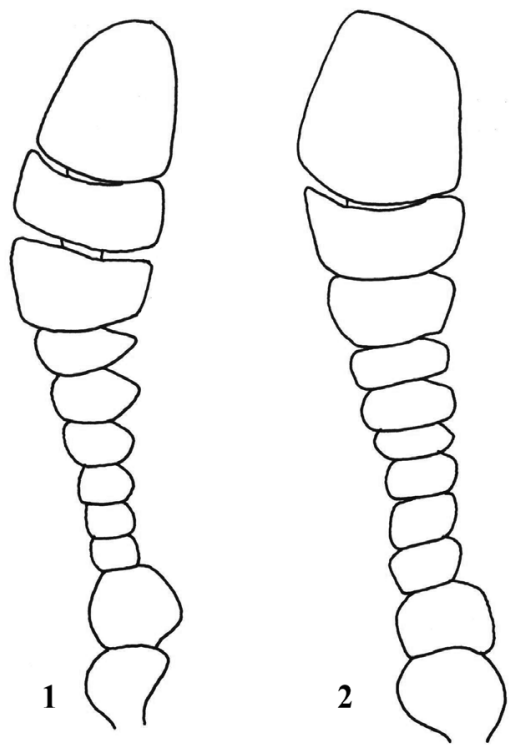

Fig. 1: Phradonoma geiseri sp. nov.: antenna of male

Fig. 2: Phradonoma tsavoensis sp. nov.: antenna of male

Phradonoma tsavoensis sp. nov. (Figs. 2,5,6)

Type material. Holotype (đ̋): Kenya, Voi (Tsavo), 8-18.11.1996, M. Snížek lgt., (BMNH). Paratypes (21 spec.): the same data as holotype, (JHAC); (1 9 ): Kenya, Tsavo Nat. Park (East), Aruba Lodge env., Satao Camp, cca $50 \mathrm{~km} \mathrm{~N}$ of Voi, $3^{\circ} 22.57^{\prime} \mathrm{S}$ 3857.46'E, 4-5.1.2011, J. Háva lgt., (JHAC).

Description of male holotype. Body black and orange-brown, longish oval. Body measurements (mm): TL 2.1 EW 1.3. Head coarsely punctuate, with short more or less decumbent brown setae, maxillary palpi dark brown, eye large with microsetae, antennae with 11 antennomeres with 5 antennomered club. The first antennomere dark brown, all other segments brown (Fig. 2). Forehead with ocellus. Pronotum entirely dark black, shiny, sparsely and not very coarsely punctate, with strong dark and slightly erect setae, white setae forming three isolated, small patches, two in lateral parts and one near scutellum. Lateral margins not visible from above. Scutellum small, black, triangular, without setation or punctures. Elytra black with orange-brown apical part, sparsely and coarsely punctate covered by sparsely, slightly erect brown and white setation. Each elytron with small isolated white spots. The underside of the specimen coarsely and (especially the visible ventrite) more densely punctate than the elytra and pronotum, covered with straight and procumbent brown setae. Tibiae and tarsi brown, femura anteriorly darkened and sparsely covered with fine brown hairs. Male genitalia as in Fig. 6, tip of median lobe as in Fig. 5.

Female. Externally very similar to male, but the antenna is a little bit shorter with a slightly smaller club.

Variabilty. Body measurements (mm): TL 2.0-3.0. The apical orange-brown area varies in size. 

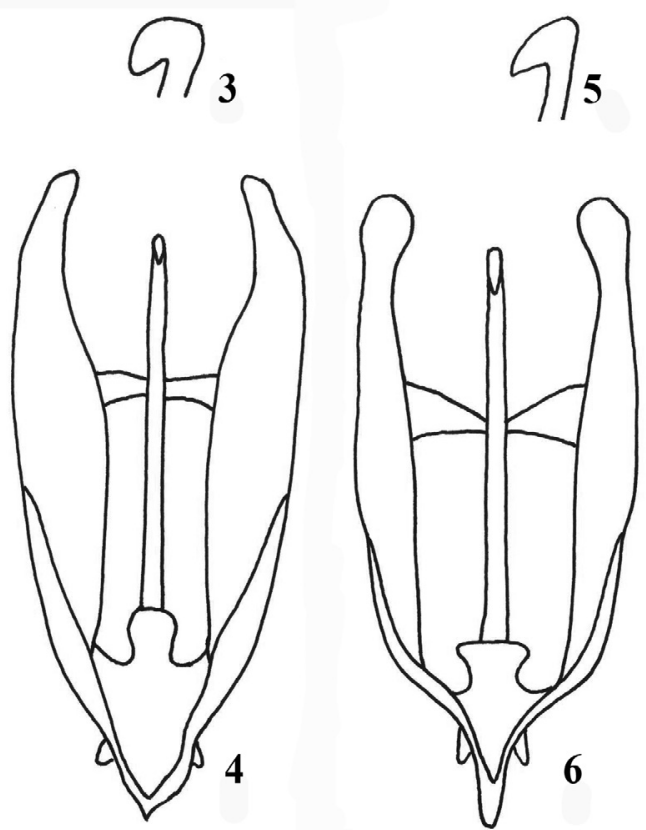

Figs. 3-4: Phradonoma geiseri sp. nov.: 3 - tip of median lobe; 4 - male genitalia, schematic Figs. 5-6: Phradonoma tsavoensis sp. nov.: 5 - tip of median lobe; 6 - male genitalia, schematic

Diagnosis. The new species belongs to the "Phradnonoma nobile species group" defined by Háva et al. (2013). The new species differs from other known Afrotropical species belonging to the species group by the characters mentioned in the following key.

Etymology. Toponymic, named according to the Kenyan National park Tsavo.

Phradonoma angelusi Háva \& Herrmann, 2009

Material examined: Kenya or., Voi (Tsavo), 8-18.11.1996, M. Snížek lgt., 29 spec., J. Háva det., (JHAC).

Distribution. Known from Cameroon and Tanzania, new to Kenya.

Phradonoma borowieci Háva \& Kadej, 2006

Material examined: Zimbabwe c., 30 km S of Harare, 30.11.1998, F. Kantner lgt., 1 , J. Háva det., (JHAC).

Distribution. Known from Botswana and South Africa, new to Zimbabwe.

Phradonoma nobile (Reitter, 1881)

Material examined: Senegal, $70 \mathrm{~km} \mathrm{~W}$ Tambacounda, $13^{\circ} 57.4^{\prime} \mathrm{N}, 1^{\circ} 15.9^{\prime} \mathrm{E}$, 29.6.2004, M. Halada lgt., 2 đ̄ Ĵ, J. Háva det., (JHAC); Senegal c., Saly env., sea coast, 2-4.2.2018, V. Novák lgt., 1 †, J. Háva det., (JHAC).

Distribution. Known from Cyprus, England (intr.), Greece, Portugal, Spain, Algeria, Egypt, Eritrea, Libya, Morocco, Nigeria, South Sudan, Sudan, Tanzania, Tunisia, Afghanistan, „Caucasus“, India: Madhya Pradesh, Rajasthan, Uttar Pradesh, Iran, Iraq, 
Israel, Jordan, Pakistan, Qatar, Saudi Arabia, Syria, Tajikistan, Turkmenistan, United Arab Emirates, Uzbekistan, USA: Arizona (intr.), Australia: Western Australia (intr.), new to Senegal.

\section{Modified key to the Afrotropical "Phradonoma nobile species group"}

1 Body form narrow, parallel, elytra without white setae, black with orange apex; antennal club with 5 antennomeres (Kenya, Namibia, Tanzania) P. babaulti

- Body form oval, elytra with brown and white or grey setae, antennal club with 3 antennomeres 2

2A Terminal antennomere triangular; elytra brownish-black except for three (sometimes only two) red, transverse bands and small circular spots covered by white setation; antennal club with 3 antennomeres (Cyprus, England (intr.), Greece, Portugal, Spain, Algeria, Egypt, Eritrea, Libya, Morocco, Nigeria, Senegal, South Sudan, Sudan, Tanzania, Tunisia, Zimbabwe, Afghanistan, „Caucasus“, India: Madhya Pradesh, Rajasthan, Uttar Pradesh, Iran, Iraq, Israel, Jordan, Pakistan, Qatar, Saudi Arabia, Syria, Tajikistan, Turkmenistan, United Arab Emirates, Uzbekistan, USA: Arizona (intr.), Australia: Western Australia (intr.))

P. nobile

2B Terminal antennomere triangular; elytra brownish-black except for three red, transverse bands and small circular spots covered by yellowish-white setation; antennal club with 5 antennomeres (Namibia, South Africa)... P. distinctum

- Terminal antennal antennomere oval ................................................................... 3

3 Elytra with light fasciae of setae and apical spot ...................................... 4

- Elytra with isolated light spots of setae ................................................................ 6

4 Elytra with one orange transverse fascia, small median orange patches and orange apical spot all covered by white setae; body length $2.30-2.70 \mathrm{~mm}$; antennal club with 3 antennomeres (Botswana, Congo, Namibia, South Africa, Tanzania, Zambia, Zimbabwe) P. eximium

- Elytra dark brown or black and dark brown without median, orange or brown patches

$5 \quad$ Elytra dark brown, each elytron covered by slightly erect dark setae with three or four fasciae and small apical spot of light brown and white setae; body length 2.10$2.60 \mathrm{~mm}$; antennal club with 3 antennomeres (Cameroon)

P. cornelli

- Elytra black in anterior half, dark brown posteriorly, each elytron with four distinct transverse fasciae of grey setae; body length $2.20 \mathrm{~mm}$; antennal club with 3 antennomeres (Angola: Bié province)

P. blabolili

6 Elytra with isolated light spots or fasciae of setae .... 7

7A Elytra black, without red, orange or brown parts. Body length 2.60-2.70 mm; antennal club with 3 antennomeres; each elytron with very small isolated 13-14 white spots (Kenya, Madagascar)

P. albonotatum

7B Elytra light brown, without red or orange parts. Body length 1.91-2.17 mm; antennal club with 5 antennomeres; each elytron with three transverse narrow fasciae of white setae (Namibia)

P. geiseri sp. nov

- Elytra with red, orange or brown parts ................................................................. 8

8A Pronotum with 5 isolated white patches, two in lateral parts, two medially and one near scutellum; body length $2.30-3.30 \mathrm{~mm}$; antennal club black with 3 antennomeres; elytra black with orange-brown apical part and with small white spots (Botswana, South Africa, Zimbabwe)

P. borowieci

8B Pronotum with 3 isolated white patches, two in lateral parts and one near scutel- 
lum; body length 2.00-3.00 mm; antennal club brown with 5 antennomeres; elytra black with orange-brown apical part and with small white spots (Kenya)

P. tsavoensis sp. nov.

- Pronotum with two lateral white patches 9

$9 \quad$ Elytra near scutellum coarsely punctured with small humeral bump; body length 2.00-2.80 mm; antennal club with 3 antennomeres; elytra black, each elytron with 12 small, distinct spots of white setae on three or four very blurred fasciae and an apical spot (Cameroon, Kenya, Tanzania).

$P$. angelusi

- Elytra near scutellum finely punctured with very large humeral bump; body length 2.40-3.20 mm; antennal club with 3 antennomeres; elytra black with orange apex, each elytron with intermixed brown setae and small patches of white setae (Namibia)

P. namibicum

\section{Acknowledgements}

I am obliged to Michael Geiser and Maxwell Barclay (BMNH) for the loan of interesting material from Namibia (Phradonoma geiseri sp. nov.).

\section{References}

HÁvA, J. 2015: World Catalogue of Insects. - Volume 13. Dermestidae (Coleoptera). Leiden/Boston: Brill, xxvi $+419 \mathrm{pp}$.

Háva, J. \& HorÁk J. 2017: Contribution to the knowledge of Dermestidae (Coleoptera) from Australia - Part 4. New faunistics records from Western Australia. - Acta Biologica Universitatis Daugavpiliensis 17(1): $1-3$.

Háva, J., Lackner, T. \& Mazancová, J. 2013: Description of Phradonoma blabolili sp. n. from Angola (Coleoptera, Dermestidae, Megatominae), with notes on the dermestid beetles from Angola. - ZooKeys 293: $65-76$. 